\title{
The Society for Textual Scholarship
}

\section{https://textualsociety.org/}

Fo

Ounded in 1979, the Society for Textual Scholarship is an international organization of scholars working in textual studies, editing and editorial theory, electronic textualities, and issues of textual culture across a wide variety of disciplines. The Society welcomes scholars from literature (in all languages), history, musicology, classical and biblical studies, philosophy, art history, legal history, history of science and technology, computer science, library science, digital humanities, lexicography, epigraphy, paleography, codicology, cinema studies, theatre, linguistics, and textual and literary theory whose work explores the ideological structures and material processes that shape the transmission, reception, production, and interpretation of texts.

The STS is devoted to providing a forum, in its conferences and its journal, for the discussion of the interdisciplinary implications of current textual research.

The Society's peer-reviewed journal Textual Cultures is published twice a year. Textual Cultures invites essays from scholars around the world in English, French, German, Spanish and Italian. All articles will appear also with abstracts in English. The submission process is now electronic; for submission instructions, visit the journal's information page @ http://www. textual-cultures.org/.

The Society's annual conferences encourage the exchange of ideas across disciplinary boundaries. An Affiliated Member of the Modern Language Association, the STS also hosts a session at the MLA's annual conference in January. For calls for papers and future conference information, please see the Society's website @ http://textualsociety.org.

Three prizes given by the STS recognize outstanding work in the field: 
The Fredson Bowers Prize is awarded for a distinguished essay in textual scholarship published in the previous two calendar years.

The Finneran Award recognizes the best edition or book about editorial theory and/or practice published in the English language during the preceding two calendar years.

The David C. Greetham Essay Prize is awarded to the best article published in the Society's journal during the two calendar years prior to the conference.

For general information regarding the Society for Textual Scholarship, please visit the Society's website (www.textual.org) or write to:

John Young Executive Director, STS

Department of English | Marshall University | Huntington, WV 25755 USA

youngj@marshall.edu

H. Wayne Storey, President, STS

Department of French and Italian, Emeritus | hstorey@indiana.edu 